\title{
Dissolution and Surface Tension Properties of Ethanol- Wash Solute Obtained from Industrial Sunflower Meal
}

\author{
Vanya Gandova $^{1(D)}$, Petya Ivanova ${ }^{2(D)}$, Hristo Kalaydzhiev ${ }^{1(D)}$, Mariana Perifanova-Nemska ${ }^{3(D)}$, Vesela $^{(1)}$ \\ I. Chalova ${ }^{2, *}$
}

1 University of Food Technologies, Department of Analytical Chemistry and Physical Chemistry, 26 Maritsa Bulv., 4002 Plovdiv, Bulgaria; gandova_71@abv.bg (V.G.); hristo.kalaydzhiev@yahoo.com (H.K.);

2 University of Food Technologies, Department of Biochemistry and Molecular Biology, 26 Maritsa Bulv., 4002 Plovdiv, Bulgaria; petia_ivanova_georgieva@abv.bg (P.I.); veselachalova@gmail.com (V.I.C);

3 University of Food Technologies, Department of Technology of Tobacco, Sugar, Vegetable and Essential Oils, 26 Maritsa Bulv., 4002 Plovdiv, Bulgaria; mariyana.perifanova@ abv.bg (M.P.N.);

* Correspondence: veselachalova@gmail.com;

Scopus Author ID 8282388500

Received: 9.11.2020; Revised: 3.12.2020; Accepted: 6.12.2020; Published: 10.12.2020

\begin{abstract}
Sunflower meal ethanol-wash solute (SEWS) is one of the products obtained from a procedure for the complete valorization of industrial sunflower meal. The meal was subjected to a 4step treatment with aqueous ethanol solution (75\%) followed by vacuum concentration and lyophilization of spent ethanol wash liquids to generate powdery SEWS. The purpose of this study was to evaluate surface tension and dissolution of SEWS in water in response to two variables, concentration $(0.1 \%, 0.3 \%, 0.5 \%)$ and temperature $\left(20^{\circ} \mathrm{C}, 30^{\circ} \mathrm{C}, 40^{\circ} \mathrm{C}, 50^{\circ} \mathrm{C}\right)$. The rate constants of $0.1 \%$ and $0.3 \%$ SEWS dissolution increased in response to temperature elevations up to $40^{\circ} \mathrm{C}$. For both concentrations, the dissolution at $50^{\circ} \mathrm{C}$ was slowed down, which resulted in deviations of the Arrhenius plot from linearity. No linear fit between rate constants and temperature increase for $0.5 \%$ SEWS was established. The addition of SEWS decreased the surface tension of pure water at all three concentrations. The most profound effect was observed at $50^{\circ} \mathrm{C}$ where water's surface tension $(67.14 \mathrm{mN} / \mathrm{m})$ was reduced 1.81 fold $(37.35 \mathrm{mN} / \mathrm{m})$ after adding $0.5 \%$ SEWS. Acquired characteristics are a valuable part of the SEWS's applicable profile needed for the potential use of the product in the food, nutraceutical, or agricultural industries.
\end{abstract}

Keywords: industrial sunflower meal; valorization; ethanol solute; dissolution; surface tension

(C) 2020 by the authors. This article is an open-access article distributed under the terms and conditions of the Creative Commons Attribution (CC BY) license (https://creativecommons.org/licenses/by/4.0/).

\section{Introduction}

Sunflower is an economically important oil-bearing crop. It is valued for its vegetable oil, produced along with substantial amounts of sunflower meal as a by-product [1]. Following soybean and rapeseed meals, the sunflower one is the third the most marketed oilseed meal worldwide. Most of it is used as a high-protein ingredient in feed formulation. However, the inclusion of the sunflower meal in animal diets is limited because of the high content of poorly digestible fibers, which may influence animal growth performance [2, 3]. According to Carellos et al. [4] and Tavernari et al. [5], the sunflower meal in feed, intended for chickens and pigs, should not exceed $16 \%$ and $20 \%$, respectively. As a result, large quantities of the meal may remain unused and turn from a by-product to a waste. The more extended storage or disposal of the sunflower meal entails additional financial costs and inefficient utilization of primary source material. 
Alternatively, the sunflower meal could be used to produce functional ingredients for the food industry [6,7]. While most studies focused on generating protein isolates and concentrates [8-10], complete valorization of the meal via transformation into multiple valueadded products has been suggested as an economically more feasible approach [11]. Major challenges in preparing sunflower meal-derived ingredients for food or nutraceutical industries are related to alteration of biochemical and techno-functional characteristics of biomacromolecules during seed pretreatments and processing that involve high temperature and chemical reagents. This might explain the limited numbers of research with industrial sunflower meal published compared to those obtained under laboratory conditions. However, although challenging, studies on sunflower meal valorization, obtained under industrial conditions, are of a greater practical application and importance.

Sunflower meal ethanol wash solute (SEWS) was obtained as a product from an integral scheme for the complete valorization of industrial sunflower meal. Preliminary biochemical evaluation of the powdery preparation revealed that it consisted of carbohydrates, lipids, and proteins. The presence of phenols and flavonoids was established, which implied potential bioactivities such as antioxidant and antimicrobial ones. To reveal the complete functional capacity of the product, more and detailed characterization is needed. One of the key features determining a new product's potential practical application is solubility in water, which is the most common solvent used in human industrial life. The purpose of this study was to evaluate surface tension and dissolution of SEWS in water in response to two variables, concentration $(0.1 \%, 0.3 \%, 0.5 \%)$ and temperature $\left(20^{\circ} \mathrm{C}, 30^{\circ} \mathrm{C}, 40^{\circ} \mathrm{C}, 50^{\circ} \mathrm{C}\right)$. Rate constants and activation energy, describing the dissolution of SEWS in water under different conditions, were established as well.

\section{Materials and Methods}

\subsection{Materials.}

Sunflower meal was obtained from a local company. It was ground and sifted $(\leq 0.315$ $\mathrm{mm}$ ) to collect uniform particles. All reagents used were of analytical grade.

\subsection{Preparation of sunflower meal ethanol-wash solute (SEWS).}

Preparation of the SEWS is outlined in Figure 1. Sunflower meal was mixed with aqueous ethanol solution (75\%) in a ration 1:4 and constantly agitated at a room temperature for $30 \mathrm{~min}$. The suspension was vacuum-filtered, and the residue was treated 3 more times in the same manner. Sequential filtrate aliquots were collected, vacuum-concentrated (RV $3 \mathrm{~V}$ Rotary Evaporator, IKA®-Werke GmbH \& Co. KG, Staufen, Germany) at $50^{\circ} \mathrm{C}$ for ethanol evaporation and freeze-dried (Lyovac GT2, Leybold-Heraeus, Germany) to prepare SEWS in a powder form.

\subsection{Evaluation of SEWS dissolution in water.}

Dissolution of SEWS in water in response to two variables, temperature $\left(20^{\circ} \mathrm{C}, 30^{\circ} \mathrm{C}\right.$, $40^{\circ} \mathrm{C}$, and $\left.50^{\circ} \mathrm{C}\right)$ and concentration $(0.1 \%, 0.3 \%$, and $0.5 \%)$, was evaluated by conductivity as described by $\mathrm{Xu}$ and Shen [12] with some modifications. Powdery SEWS samples were weighted and added to $50 \mathrm{ml}$ distilled water tempered to $30^{\circ} \mathrm{C}, 40^{\circ} \mathrm{C}$, or $50^{\circ} \mathrm{C}$ to achieve the 
desired concentration. The conductivity measurement (Bante510, Bante Instruments, Woodbury, CT) was started immediately after the samples' addition.

Sunflower meal, grinded and sifted

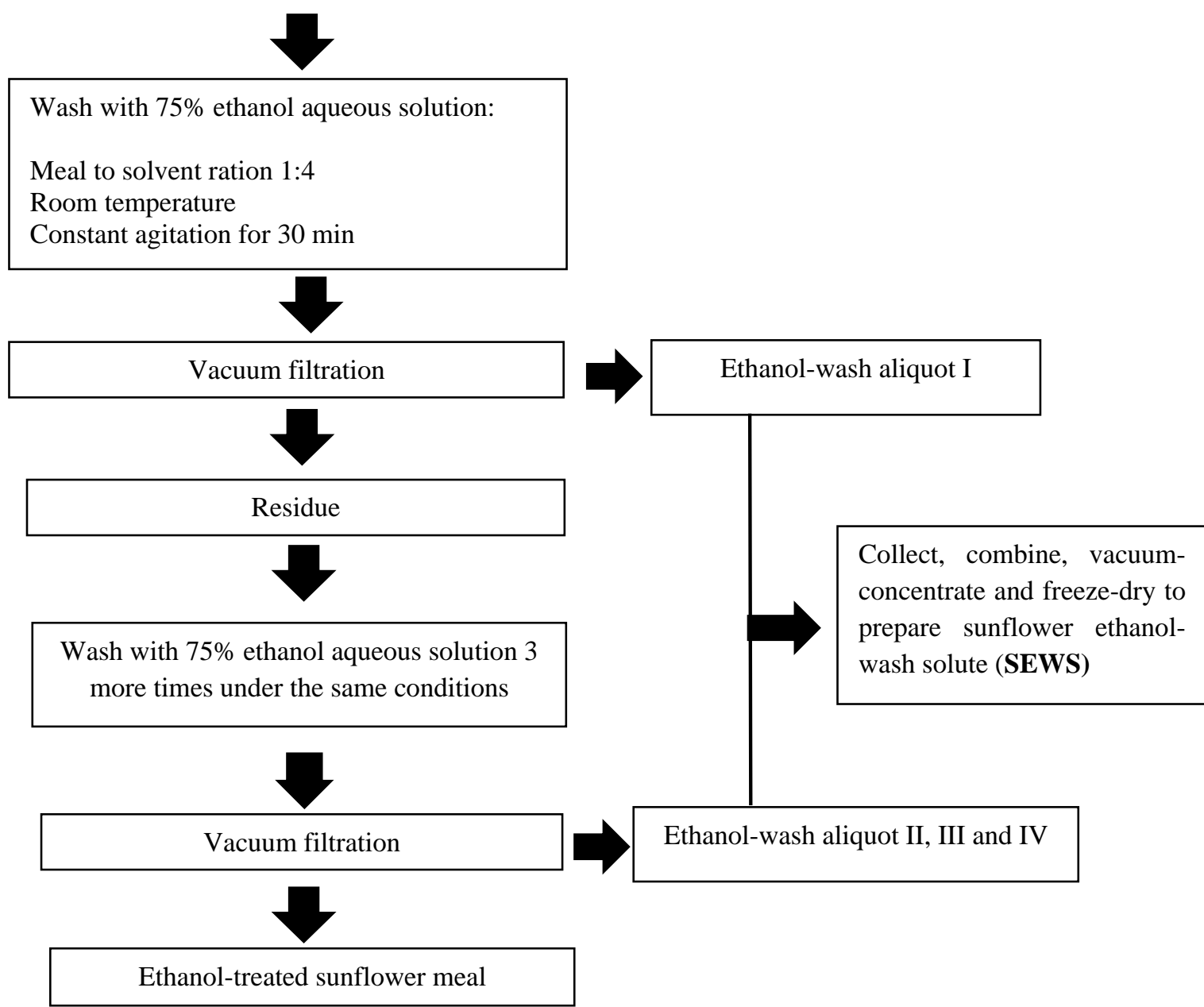

Figure 1. Preparation of sunflower ethanol-wash solute (SEWS) from industrial sunflower meal.

The evaluation was performed under constant agitation (400 rpm) and temperature, maintained by an electromagnetic stirrer (MS-H280-Pro, Dragon Laboratory Instruments, Beijing, China). The maximum deviation in temperature was $\pm 0.5^{\circ} \mathrm{C}$. Data were recorded manually in a 2-second period until reaching stable observations.

The rate constant, $\mathrm{k}(1 / \mathrm{s})$, and activation energy, Ea $(\mathrm{kJ} / \mathrm{mol})$, were determined to characterize the process better. The rate constants were established by following Guggenheim's method [13]. The method is based on recording a set of data at chosen times and a time shift that remains constant. The following kinetic equation (1) for the conductance dependence was used:

$\ln \left(\mu \mathrm{t}+\mathrm{t}^{\prime}-\mu \mathrm{t}\right)=\mathrm{A}-\mathrm{kt}$

where $\mu(\mu \mathrm{S} / \mathrm{cm})$ were the experimental conductivity measures recorded at time $\mathrm{t}(\mathrm{s})$ and $\mathrm{t}^{\prime}(\mathrm{s})$ is the time shift chosen. A time shift of $10 \mathrm{~s}$ was used in the current study. The rate constants were obtained as slopes of fitted plots of the function (2):

$\ln \left(\mu_{\mathrm{t}+\mathrm{t}^{\prime}}-\mu_{\mathrm{t}}\right)=f(\mathrm{t})$ 
For calculation of activation energy, Arrhenius equation (3) was used:

$\ln k=\frac{-E a}{R} \cdot \frac{1}{T}+\ln A$

where $\mathrm{R}$ is the gas constant, $8.314 \mathrm{~J} /(\mathrm{mol} . \mathrm{K})$, and $\mathrm{T}$ is temperature $(\mathrm{K})$.

The logarithm of the rate constant was plotted versus inverse temperature, $1 / \mathrm{T}$, and the slope of the linear plot was used to calculate $E_{a}$ by the equation (4):

slope $=\frac{-E a}{R}$

\subsection{Evaluation of surface tension.}

Surface tension was evaluated by using the maximum bubble pressure method, as previously described [14]. Rebinder apparatus was used for the implementation of the experiments. Thermostatted water was pumped continuously to maintain the desired temperature. Surface tension was calculated by equation (5):

$\gamma=(\mathrm{rg} / 2)\left(\Delta \mathrm{H} \rho_{\mathrm{o}}-\mathrm{r} \rho\right)$

where $r$ is the radius of the capillary, $\mathrm{m} ; \mathrm{g}=9.8 \mathrm{~m} / \mathrm{s}-$ the acceleration of gravity; $\Delta \mathrm{H}-$ the maximum difference in the two gauges of the gauge, $\mathrm{m} ; \rho \circ, \rho-$ the density of the manometric (water) and test liquid, $\mathrm{kg} / \mathrm{m} 3$.

\subsection{Statistical analyses.}

Experiments were performed in triplicates. Results were presented as means \pm standard deviation (SD). Differences were considered significant at $\alpha=0.05$.

\section{Results and Discussion}

\subsection{Preparation of sunflower meal ethanol-wash solute (SEWS).}

After oil extraction, the sunflower meal produced contains a relatively high amount of proteins, which may vary from $30 \%$ to $50 \%$ (dry matter basis) depending on plant variety, climate conditions, and soil characteristics $[15,16]$. In addition to being used as a feed ingredient, the sunflower meal is considered a valuable source for the preparation of protein isolates or concentrates for human nutrition [8-10]. However, sunflower meal contains a substantial amount of phenols, with chlorogenic acid being the predominant one. In the typical procedure for protein isolate preparation, the phenols solubilize with proteins. They remain as concomitant compounds in the final product. While valued for their antioxidant and antibacterial properties, phenols are responsible for forming unsuitable brawn-greenish color and off-flavors of protein isolates. Therefore, their presence in the sunflower meal is undesired [17]. In our laboratory, a 4-step treatment of the sunflower meal with $75 \%$ aqueous ethanol solution is routinely used to prepare a meal with a reduced phenols level. By following the same procedure, Kalaydzhiev et al. [18] achieved a 4-fold decrease in industrial rapeseed meal phenol content. Similar results were obtained by Chabanon et al. [19] and Ivanova et al. [20]. Since the procedure was designated for higher-quality protein isolates, ethanol-wash liquids remained a waste. However, after collecting, concentrating, and freeze-drying, the spent 
ethanol-wash liquids turned into a new powdery product, named SEWS. Preliminary analyses revealed that it consisted mainly of carbohydrates (approximately 55\%), followed by lipids and proteins. The product contained less than $10 \%$ phenols and flavonoids, which implied potential antioxidant and antimicrobial activities. Therefore, the SEWS might be useful as an ingredient/additive in the food, nutraceutical, or agricultural industries, which could be determined after detailed evaluation and characterization. Sufficient solubility of plant-derived bioactive compounds in the water is essential for achieving optimal expression of their properties and efficiency in a wide range of potential applications [21].

\subsection{Dissolution of SEWS in water.}

Multiple factors influence solid dissolution patterns in a solvent as temperature and concentration are among the most important ones [22]. The concentration's influence was evaluated at three levels, namely, $0.1 \%, 0.3 \%$, and $0.5 \%$, related to the potential application of the SEWS as an additive in the food industry [23]. Food additives do not have nutritive value but are supplemented in small amounts, affect a product's techno-functional characteristics [24]. Allowable doses are highly variable and dependent on the additive nature and related risk assessment [25]. Water was the most commonly used solvent in industrial processes [26].

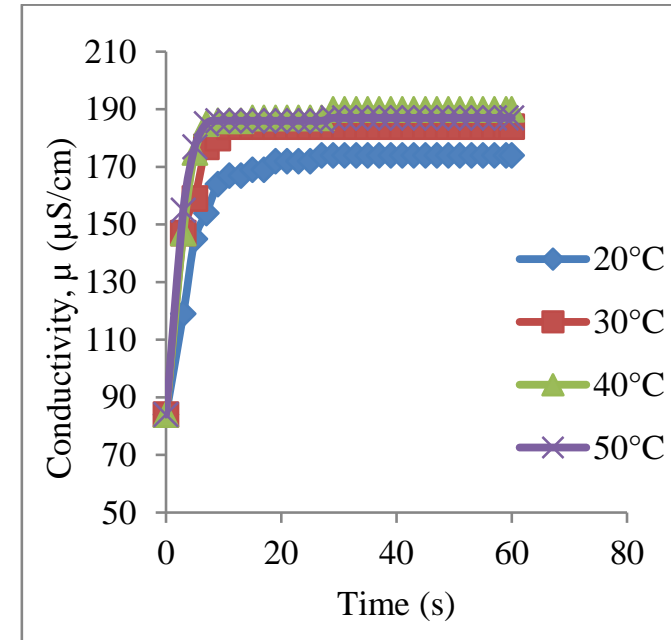

(a)

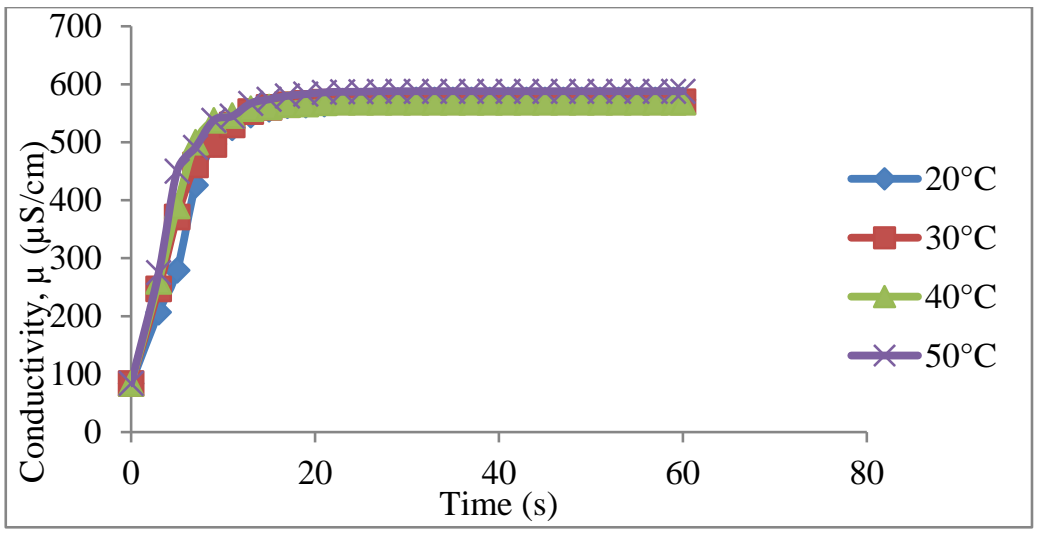

(c)

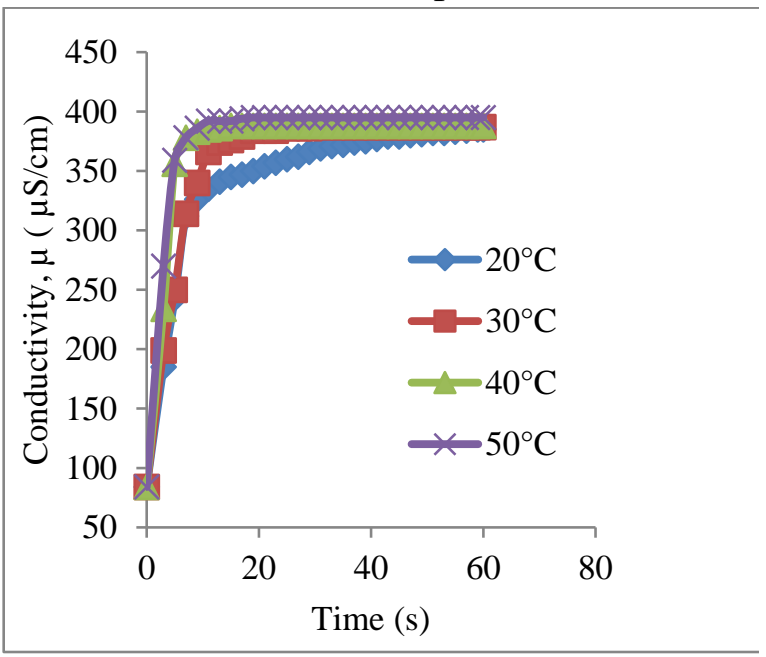

(b)

Figure 2. Dissolution of $0.1 \%(\mathbf{a}), 0.3 \%$ (b) and $0.5 \%$ (c) sunflower meal ethanol-wash solute (SEWS) in water at different temperatures, $20^{\circ} \mathrm{C}, 30^{\circ} \mathrm{C}, 40^{\circ} \mathrm{C}$ and $50^{\circ} \mathrm{C}$. Data are mean values of three experiments \pm standard deviation, which did not exceed 20.

The SEWS dissolution behavior in water was evaluated by conductivity measures (Figure 2). The method is suitable for use in the pharmaceutical and food industries. The 
dissolution of materials with a composite nature is characterized by undefined intermediate concentrations [27, 28]. The dissolution of the SEWS in water was influenced by both temperature and concentrations. For all three concentrations, maximum conductivity was achieved at $50^{\circ} \mathrm{C}$ (Figure 2). The SEWS's dissolution in water was highly responsive to temperature increases, as evidenced by high-rate constants (Table 1). The rate constants of $0.1 \%$ SEWS followed the increase of the temperature proportionally up to $40^{\circ} \mathrm{C}$ as the trend was characterized by high linearity $\left(\mathrm{R}^{2}=0.99\right)$ (Figure 3 ).

Table 1. Kinetic parameters of sunflower meal ethanol-wash solute (SEWS) dissolution in water.

\begin{tabular}{c|c|c|c|c|c|}
\multirow{2}{*}{$\begin{array}{c}\text { SEWS } \\
\text { concentration } \\
(\%)\end{array}$} & \multicolumn{4}{|c}{ Rate constant, k (1/s) } & $\begin{array}{c}\text { Activation } \\
\text { energy, Ea } \\
(\mathbf{k J} / \mathbf{m o l})\end{array}$ \\
\cline { 2 - 6 } & $20^{\circ} \mathrm{C}$ & $30^{\circ} \mathrm{C}$ & $40^{\circ} \mathrm{C}$ & 0.919 & $56.81^{*} \mathrm{C}$ \\
\hline 0.1 & 0.202 & 0.448 & 0.896 & 0.388 & $13.83^{*}$ \\
\hline 0.3 & 0.271 & 0.311 & 0.390 & 0.230 & $\mathrm{ND}$
\end{tabular}

$*$ Calculated from linear Arrhenius plot from $20^{\circ} \mathrm{C}$ to $40^{\circ} \mathrm{C}$

ND: not determined

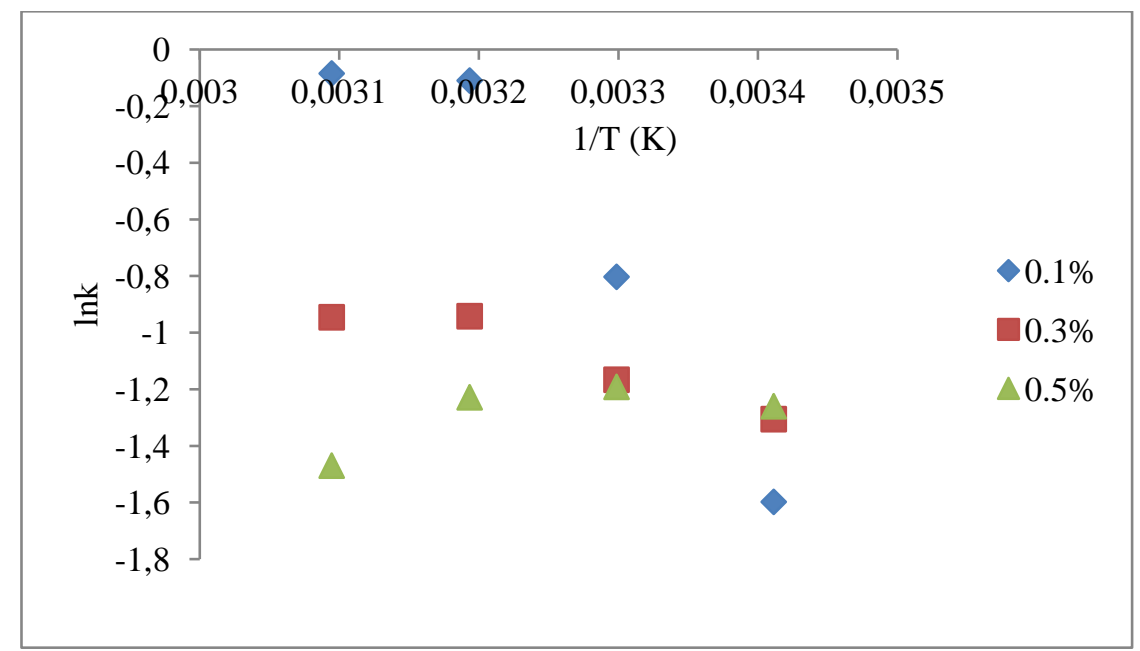

Figure 3. Plot of the natural $\log$ of the rate constant of $0.1 \%, 0.2 \%$, and $0.3 \%$ SEWS dissolution in water versus inverse temperature $(\mathrm{K})$.

A linear response of the rate constants of $0.3 \%$ SEWS to increasing temperatures up to $40^{\circ} \mathrm{C}$ was observed as well. However, this concentration's dissolution was affected by the temperature at a lower extend compared to $0.1 \%$ SEWS (Table 1). Consequently, the steeper slope of $0.1 \%$ SEWS determined the higher activation energy $(56.81 \mathrm{~kJ} / \mathrm{mol}$, Table 1) compared to the one of $0.3 \%$ SEWS $(13.83 \mathrm{~kJ} / \mathrm{mol}$, Table 1$)$. For both concentrations, the dissolution at $50^{\circ} \mathrm{C}$ was slowed down, which resulted in deviations of the Arrhenius plot from linearity at this temperature (Figure 3). No linear fit between rate constants and temperature increase for $0.5 \%$ SEWS was established. Instead, the dissolution process of that sample at different temperatures was outlined by a curvature (Figure 3). Similar deviations from Arrhenius plots have previously been reported and explained by the increase of sample viscosity [29]. While for pure inorganic chemical compounds, the increase in temperature decreases the viscosity of solutions. The temperature enhancement may increase the viscosity of composite materials consisting of various bio-macromolecules. It is probably due to conformational changes occurring with macromolecules such as carbohydrates, lipids, and proteins. This might explain the relatively lower rate constants of dissolution of the $0.5 \%$ SEWS compared to $0.1 \%$ and $0.3 \%$ SWES at all temperatures (Table 1) and the deviations of the latter two concentrations from the linearity of the Arrhenius plots at $50^{\circ} \mathrm{C}$. 


\subsection{Influence of SEWS concentration and temperature on surface tension.}

Surface tension is an important characteristic which would affect the applicability range of SEWS. It is valuable information concerning the formulation, fabrication process, or final product quality where the SEWS would be added as a supplement [30]. The surface tension of water was reduced by all three SEWS concentration levels studied (Figure 4). A higher decrease of surface tension was achieved by $0.5 \%$ SEWS compared to $0.1 \%$ and $0.3 \%$

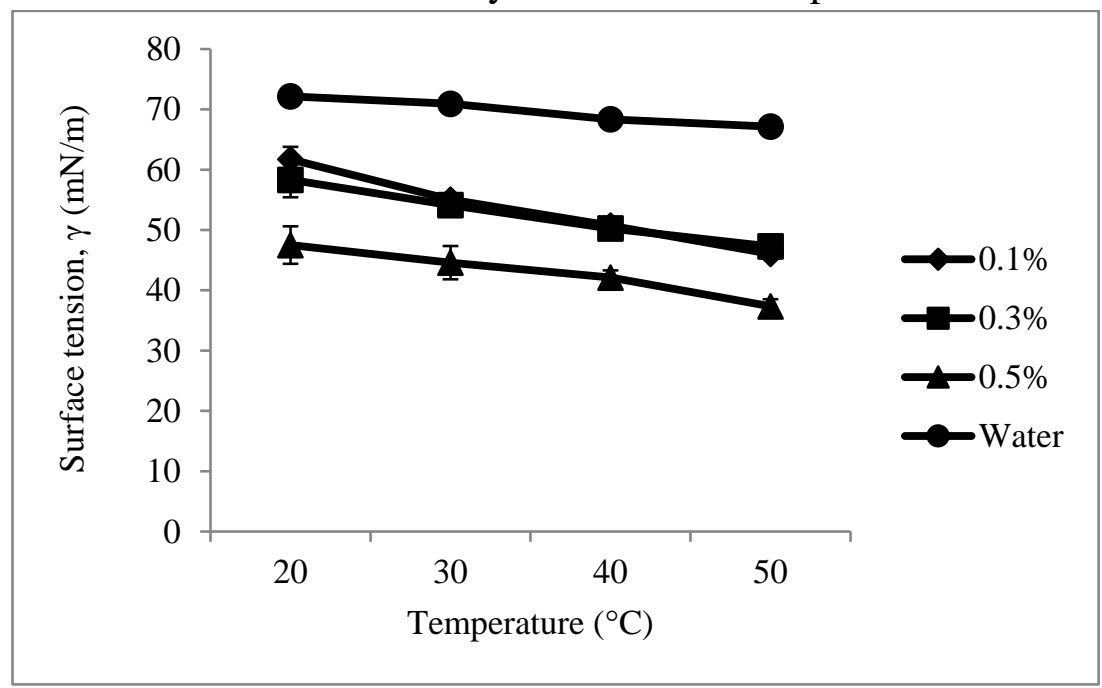

Figure 4. Influence of SEWS concentrations and temperature on surface tension $\gamma(\mathrm{mN} / \mathrm{m})$.

SEWS as no significant differences between the latter two were observed $(\mathrm{p}<0.05)$. The influence of the concentrations on the surface tension was more profound at the highest temperature studied. The addition of $0.5 \%$ SEWS to water resulted in a 1.81-fold decrease of surface tension at $50^{\circ} \mathrm{C}$ compared to a 1.53 -fold decrease at $20^{\circ} \mathrm{C}$. Data demonstrated that SEWS exhibited surface activity as the exact mechanism is still unknown. A straightforward explanation for the observed phenomenon is difficult to achieve because of the high complexity of the SEWS composition. The product consists of various biomolecules with different structures and molecular weights, including carbohydrates, lipids, and proteins. Some molecules probably have both polar or hydrophilic and nonpolar or lipophilic groups concentrating at the water-air interface. Formation of micelle-like structures is not excluded, especially at the highest SEWS concentration (0.5\%) studied. Finally, some intermolecular interactions might occur, leading to reduced surface tension [31].

Surface-active compounds are widely used in the food industry. Although supplemented in small amounts, they influence colloid systems' stability, organoleptic properties of final products, moisture retention, and product shelf life [32]. There is increasing interest in the replacement of synthetic surfactants with natural compounds having similar properties in recent years. It is defined by customers' enhancing demand for healthier and safer food, careful utilization of natural resources, and stimulation of the local economy where possible [33]. Surface active properties combined with bioactive capacity (data not shown) defined the SEWS as a value-added product from the vegetable oil-producing industry with potential application in food, nutraceutical, or agricultural industries.

\section{Conclusions}

SEWS is a new product obtained as a part of an integral scheme for the complete valorization of industrial sunflower meal. The product was highly soluble in water as the 
dissolution rate was dependent on both concentration and temperature. The dissolution of the highest concentrations studied $(0.5 \%)$ deviated from the Arrhenius plot's linearity, which was most probably due to enhanced viscosity and conformational alterations of biomacromolecules composing the SEWS. The product demonstrated surface-active properties, which define its potential as an additive in various industrial applications.

\section{Funding}

This research was funded by Bulgarian National Science Fund, grant number KП-06-H37/21. "An integrated approach for efficient utilization of by-products of vegetable oil-producing industry: Sunflower and rapeseed meals".

\section{Acknowledgments}

This research has no acknowledgment.

\section{Conflicts of Interest}

The authors declare no conflict of interest.

\section{References}

1. Pilorgé, E. Sunflower in the global vegetable oil system: situation, specificities and perspectives. OCL 2020, 27, 34, https://doi.org/10.1051/ocl/2020028.

2. Waititu, S.M.; Sanjayan, N.; Hossain, M.M.; Leterme, P.; Nyachoti, C.M. Improvement of the nutritional value of high-protein sunflower meal for broiler chickens using multi-enzyme mixtures. Poult. Sci. 2018, 97, 1245-1252, https://doi.org/10.3382/ps/pex418.

3. Ciurescu, G.; Vasilachi, A.; Grigore, D.; Grosu, H. Growth performance, carcass traits, and blood biochemistry of broiler chicks fed with low-fibre sunflower meal and phytase. S. Afr. J. Anim. Sci. 2019, 49, 735-745, https://doi.org/10.4314/sajas.v49i4.15.

4. Carellos, D.d.C.; Lima, J.A.d.F.; Fialho, E.T.; Freitas, R.T.F.d.; Silva, H.O.; Branco, P.A.C.; Souza, Z.A.d.; Vieira Neto, J. Evaluation of sunflower meal on growth and carcass traits of finishing pigs. Ciência $e$ Agrotecnologia 2005, 29, 208-215, https://doi.org/10.1590/S1413-70542005000100026.

5. Tavernari, F.C.; Albino, L.F.T.; Morata, R.L.; Dutra Júnior, W.M.; Rostagno, H.S.; Viana, M.T.S. Inclusion of sunflower meal, with or without enzyme supplementation, in broiler diets. Brazilian Journal of Poultry Science 2008, 10, 233-238, https://doi.org/10.1590/S1516-635X2008000400007.

6. Grasso, S.; Liu, S.; Methven, L. Quality of muffins enriched with upcycled defatted sunflower seed flour. LWT 2020, 119, 108893, https://doi.org/10.1016/j.lwt.2019.108893.

7. Adeleke, B.S.; Babalola, O.O. Oilseed crop sunflower (Helianthus annuus) as a source of food: Nutritional and health benefits. Food Science \& Nutrition 2020, 8, 4666-4684, https://doi.org/10.1002/fsn3.1783.

8. Kalaydzhiev, H.; Ivanova, P.; Silva, C.L.M.; Chalova, V.I. Functional Properties of Protein Isolate and Acid Soluble Protein-Rich Ingredient Co-Produced from Ethanol-Treated Industrial Rapeseed Meal. Pol. J. Food Nutr. Sci. 2019, 69, 129-136, https://doi.org/10.31883/pjfns-2019-0007.

9. Malik, M.A.; Saini, C.S. Heat treatment of sunflower protein isolates near isoelectric point: Effect on rheological and structural properties. Food Chem. 2019, 276, 554-561, https://doi.org/10.1016/j.foodchem.2018.10.060.

10. Laguna, O.; Barakat, A.; Alhamada, H.; Durand, E.; Baréa, B.; Fine, F.; Villeneuve, P.; Citeau, M.; Dauguet, S.; Lecomte, J. Production of proteins and phenolic compounds enriched fractions from rapeseed and sunflower meals by dry fractionation processes. Industrial Crops and Products 2018, 118, 160-172, https://doi.org/10.1016/j.indcrop.2018.03.045.

11. Ancuța, P.; Sonia, A. Oil Press-Cakes and Meals Valorization through Circular Economy Approaches: A Review. Applied Sciences 2020, 10, 7432, https://doi.org/10.3390/app10217432.

12. Xu, Y.; Shen, Q. Dynamic dissolution of persimmon leaves in DMSO and DMAc and the influence of acidbase interactions. Colloids Surf. B. Biointerfaces 2006, 47, 98-101, https://doi.org/10.1016/j.colsurfb.2005.11.027.

13. Niebergall, P.J.; Sugita, E.T. Utilization of the Guggenheim Method in Kinetics. J. Pharm. Sci. 1968, 57, 1805-1808, https://doi.org/10.1002/jps.2600571045. 
14. Tasheva, S.; Gandova, V.; Dobreva, K.; Dincheva, I.; Prodanova-Stefanova, V.; Stoyanova, A. Studies of physicochemical and thermal properties of linalool-ethanol-water system. Res. J. Pharm. Biol. Chem. Sci. 2019, 10(6), 220-227, https://doi.org/10.33887/rjpbcs/2019.10.6.27.

15. González-Pérez, S.; Vereijken, J.M. Sunflower proteins: overview of their physicochemical, structural and functional properties. J. Sci. Food Agric. 2007, 87, 2173-2191, https://doi.org/10.1002/jsfa.2971.

16. La Bella, S.; Tuttolomondo, T.; Lazzeri, L.; Matteo, R.; Leto, C.; Licata, M. An agronomic evaluation of new safflower (Carthamus tinctorius L.) germplasm for seed and oil yields under Mediterranean climate conditions. Agronomy 2019, 9, 468, https://doi.org/10.3390/agronomy9080468.

17. Albe Slabi, S.; Mathé, C.; Framboisier, X.; Defaix, C.; Mesieres, O.; Galet, O.; Kapel, R. A new SE-HPLC method for simultaneous quantification of proteins and main phenolic compounds from sunflower meal aqueous extracts. Anal. Bioanal. Chem. 2019, 411, 2089-2099, https://doi.org/10.1007/s00216-019-016352 .

18. Kalaydzhiev, H.; Ivanova, P.; Stoyanova, M.; Pavlov, A.; Rustad, T.; Silva, C.L.M.; Chalova, V.I. Valorization of Rapeseed Meal: Influence of Ethanol Antinutrients Removal on Protein Extractability, Amino Acid Composition and Fractional Profile. Waste and Biomass Valorization, https://doi.org/10.1007/s12649-018-00553-1.

19. Chabanon, G.; Chevalot, I.; Framboisier, X.; Chenu, S.; Marc, I. Hydrolysis of rapeseed protein isolates: Kinetics, characterization and functional properties of hydrolysates. Process Biochem. 2007, 42, 1419-1428, https://doi.org/10.1016/j.procbio.2007.07.009.

20. Ivanova, P.; Kalaydzhiev, H.; Rustad, T.; Silva, C.L.M.; Chalova, V.I. Comparative biochemical profile of protein-rich products obtained from industrial rapeseed meal. Emirates Journal of Food and Agriculture 2017, 170-178, https://doi.org/10.9755/ejfa.2016-11-1760.

21. Alfei, S. Nanotechnology Applications to Improve Solubility of Bioactive Constituents of Foods for HealthPromoting Purposes. In Nano-food Engineering, Springer: 2020; 189-257, https://doi.org/10.1007/978-3030-44552-2_8.

22. Liu, X.; Mäki-Arvela, P.; Aho, A.; Vajglova, Z.; Gun'ko, V.M.; Heinmaa, I.; Kumar, N.; Eränen, K.; Salmi, T.; Murzin, D.Y. Zeta potential of beta zeolites: Influence of structure, acidity, $\mathrm{pH}$, temperature and concentration. Molecules 2018, 23, 946, https://doi.org/10.3390/molecules23040946.

23. Chan, P.N.A. Chemical properties and applications of food additives: Preservatives, dietary ingredients, and processing aids. In Handbook of Food Chemistry; Cheung, P. Mehta, B., Eds; Springer: Berlin, Germany, 2015; 101-129, https://doi.org/10.1007/978-3-642-36605-5_37.

24. Martins, F.C.O.L.; Sentanin, M.A.; De Souza, D. Analytical methods in food additives determination: Compounds with functional applications. Food Chem. 2019, 272, 732-750, https://doi.org/10.1016/j.foodchem.2018.08.060.

25. Faustino, M.; Veiga, M.; Sousa, P.; Costa, E.M.; Silva, S.; Pintado, M. Agro-food by-products as a new source of natural food additives. Molecules 2019, 24, 1056, https://doi.org/10.3390/molecules24061056.

26. Guo, Z.; Wang, T.; Wei, H.; Long, Y.; Yang, C.; Wang, D.; Lang, J.; Huang, K.; Hussain, N.; Song, C. Ice as solid electrolyte to conduct various kinds of ions. Angew. Chem. 2019, 131, 12699-12703, https://doi.org/10.1002/ange.201907832.

27. Marabi, A.; Raemy, A.; Bauwens, I.; Burbidge, A.; Wallach, R.; Saguy, I.S. Effect of fat content on the dissolution enthalpy and kinetics of a model food powder. J. Food Eng. 2008, 85, 518-527, https://doi.org/10.1016/j.jfoodeng.2007.08.012.

28. Salman, Y.A.K.; Abdullah, O.G.; Hanna, R.R.; Aziz, S.B. Conductivity and electrical properties of chitosanmethylcellulose blend biopolymer electrolyte incorporated with lithium tetrafluoroborate. Int. J. Electrochem. Sci 2018, 13, 3185-3199, https://doi.org/10.20964/2018.04.25.

29. Carvalho-Silva, V.H.; Coutinho, N.D.; Aquilanti, V. Temperature dependence of rate processes beyond Arrhenius and Eyring: Activation and Transitivity. Frontiers in Chemistry 2019, 7, 380, https://doi.org/10.3389/fchem.2019.00380.

30. Liu, X.; Wang, L.; Qiao, Y.; Sun, X.; Ma, S.; Cheng, X.; Qi, W.; Huang, W.; Li, Y. Adhesion of liquid food to packaging surfaces: Mechanisms, test methods, influencing factors and anti-adhesion methods. J. Food Eng. 2018, 228, 102-117, https://doi.org/10.1016/j.jfoodeng.2018.02.002.

31. Olayiwola, S.O.; Dejam, M. Mathematical modelling of surface tension of nanoparticles in electrolyte solutions. Chem. Eng. Sci. 2019, 197, 345-356, https://doi.org/10.1016/j.ces.2018.11.047.

32. Sharma, R.K. Surfactants: basics and versatility in food industries. PharmaTutor 2014, 2, 17-29.

33. Rizzo, G.; Borrello, M.; Dara Guccione, G.; Schifani, G.; Cembalo, L. Organic food consumption: The relevance of the health attribute. Sustainability 2020, 12, 595, https://doi.org/10.3390/su12020595. 